„Przekłady Literatur Słowiańskich”. T. 11, cz. 1, s. 1-20

ISSN 2353-9763 (wersja elektroniczna)

DOI https://doi.org/10.31261/PLS.2021.11.01.11

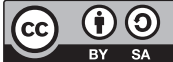

\title{
Długa droga do litewskiego przekładu Traktatu poetyckiego Czesława Miłosza
}

\section{A Long Way to the Lithuanian Translation of Czesław Miłosz's A Treatise on Poetry}

\author{
Beata Kalęba \\ iD https://orcid.org/0000-0003-0564-0210 \\ JAGIELLONIAN UNIVERSITY IN KRAKÓW \\ beata.kaleba@uj.edu.pl \\ Data zgłoszenia: 27.02.2021 r. | Data akceptacji: 12.06.2021 r.
}

\begin{abstract}
The article is devoted to the reception of Czesław Miłosz's body of work in translations into Lithuanian language as well as his cooperation with Lithuanian authors. The issue addressed is the reception of Miłosz's work among the writers of the "Literatūros lankai" emigrant journal and in Tomas Venclova's eyes, who himself is one of the main translators of Miłosz into Lithuanian, and the author of a newly published traduction of his A Treatise on Poetry.
\end{abstract}

KEYWORDS | translation, Czesław Miłosz, Tomas Venclova, A Treatise on Poetry, Lithuanian language 
Na początku 2021 roku w wileńskim wydawnictwie Apostrofa ukazał się Traktat poetycki Czesława Miłosza w tłumaczeniu Tomasa Venclovy ${ }^{1}$. Dziesięć lat wcześniej, w wydanym z okazji 100-lecia urodzin Miłosza litewskim wyborze jego wierszy, opublikowano Traktat teologiczny w przekładzie poety i tłumacza z języków słowiańskich Almisa Grybauskasa; jest to więc drugi z trzech Miłoszowych „nie traktatów, a traktatów wierszem”2 dostępny dla litewskiego czytelnika.

Na język litewski przełożono wiele dzieł Miłosza; oczywiście większość z nich została wydana w niepodległej Litwie w ostatniej dekadzie XX wieku oraz po 2000 roku - przede wszystkim z okazji jubileuszu 100-lecia urodzin poety (w kolejności chronologicznej są to tłumaczenia: Doliny Issy — już w 1991, Poszukiwania ojczyzny, Zniewolonego umystu, Historii literatury polskiej, Ziemi Ulro, Czesława Miłosza autoportretu przekornego, Pieska przydrożnego, Rodzinnej Europy, Wyprawy w dwudziestolecie, Świadectwa poezji, Abecadła - 2012) ${ }^{3}$. W osobnych wydaniach ukazał się w Litwie między innymi wykład noblowski (2001) oraz Czeladnik z tomu Druga przestrzeń, a także przekład zbioru To. Obszerny wybór wierszy (ponad 380 s.) opublikowano w latach 90. XX stulecia, a następnie - uzupełniony - w 2011 roku. Litwini przełożyli także wybory korespondencji Czesława Miłosza z Jerzym Giedroyciem oraz wydany przez Zeszyty Literackie zbiór dokumentujący ludzki i literacki dialog Miłosza i Tomasa Venclovy Powroty do Litwy ${ }^{4}$. Większość publikacji z lat 90. mogła się ukazać

1 Edycja jest dwujęzyczna: C. Miłosz, 2021: Traktat poetycki z moim komentarzem. Poetinis traktatas su mano komentarais. T. Venclova, $\mathfrak{i}$ lietuvių kalbą vertè. Vilnius, Apostrofa. Tłumacz oraz wydawca litewski korzystali z wydania polskiego: C. Miłosz, 2001: Traktat poetycki z moim komentarzem. Kraków, Wydawnictwo Literackie. Przekład litewski powstał w roku 2019; fragment (Duch dziejów) został opublikowany w miesięczniku „Metai” 2019, nr 10. Warto wspomnieć, że w 2015 roku ta sama oficyna wydawnicza - Apostrofa - udostępniła czytelnikowi litewskiemu biografię Miłosza autorstwa Andrzeja Franaszka (tłum. Vytas Dekšnys).

2 Parafraza słów Natalii Gorbaniewskiej o Traktacie poetyckim; N. Gorbaniewska, 2012: Nie traktat, a traktat wierszem. „Poznańskie Studia Polonistyczne”, nr 20, s. 211.

3 Isos slènis, tłum. Algis Kalèda, 1991; Tèvynès ieškojimas, tłum. Algis Kalèda, 1995; Pavergtas protas, tłum. Almis Grybauskas, 1995; Lenku literatūros istorija, tłum. Kornelijus Platelis, 1996; Ulro žemè, tłum. Almis Grybauskas, 1996; Maištingas Czesławo Miłoszo autoportretas, tłum. Birute Jonuškaitè, 1997; Pakelès šunytis, tłum. Vyturys Jarutis, 2000; Gimtoji Europa, tłum. Juozas Tumelis, 2003; Išvyka i Dvidešimtmeti, tłum. Laura Liubinavičiūte, 2003; Poezijos liudijimas, tłum. Brigita Speičytė i Mindaugas Kvietkauskas, 2010; Abécèlè, tłum. Vytautas Dekšnys, 2012.

4 Nobelio paskaita Švedijos mokslu akademijoje, tłum. Barbara Kalèdienè i Algis Kalèda, 2001; Pameistrys, tłum. Almis Grybauskas, 2002; Tai, tłum. Vyturys Jarutis, 2002; dwujęzyczny wybór wierszy: Rinktiniai eilèračiai - Poezje wybrane, tłum. Vytautas Ališauskas et al., oprac. A. Kaleda, 1997; uzupełniony wybór wierszy Rinktiniai eilèraščiai, tłum. Eugenijus Ališanka et al., oprac. A. Kalèda i B. Speičyte, 2011; Jerzy 
dzięki wsparciu Fundacji Otwartej Litwy (Atviros Lietuvos fondas), zgodnie z jej ideami budowania świadomych, obywatelskich społeczeństw w państwach postsowieckich. Natomiast po 2000 roku tłumaczenia dzieł Miłosza oraz różne publikacje okolicznościowe wydawano w Litwie przede wszystkim po śmierci poety oraz z okazji 100. rocznicy jego urodzin ${ }^{5}$. Twórczość Czesława Miłosza jest dziś obecna także w programie nauczania języka litewskiego i literatury dla starszych klas szkół średnich. Wśród rekomendowanych utworów nadobowiązkowych znalazły się: Dolina Issy oraz wiersze - W mojej ojczyźnie..., Campo di Fiori, Mittelbergheim, Nigdy od ciebie, miasto..., Rue Descartes, Ryba, Godzina, Filologija oraz Dwór i Łąka z cyklu Litwa po pięćdziesięciu dwóch latach. Uczniowie polskich szkół średnich poza wspomnianymi tekstami zapoznają się także w ramach lektur nadobowiązkowych — z Rodzinną Europa, Szukaniem ojczyzny, Zniewolonym umysłem i Pieskiem przydrożnym. Jak łatwo zauważyć, zwłaszcza w szkołach litewskich istotnym - choć przecież nie jedynym - kluczem doboru zalecanych do lektury utworów Miłosza jest tematyka bądź motywy związane z ojczystymi stronami poety i szerzej - z Litwą. Drugim ważnym tematem, kojarzonym za sprawą szkoły z nazwiskiem Miłosza, jest Holokaust; bywa, że oprócz wiersza Campo di Fiori absolwenci szkół litewskich znają także Piosenkę o końcu świata oraz esej Biedny chrześcijanin patrzy na getto ${ }^{6}$. Zasadniczo podobnie rozkładają się akcenty w pracach litewskich badaczy poświęconych twórczości i biografii Czesława Miłosza oraz ich kontekstom. Jego litewska monografia, autorstwa Viktoriji Daujotyte i Mindaugasa Kvietkauskasa, nosi tytuł Litewskie konteksty Czesława Miłosza. Również wydane po 2000 roku prace zbiorowe oraz monograficzne numery czasopism - zresztą przygotowywane głównie w kręgu kowieńskiego Uniwersytetu im. Witolda Wielkiego, sprawującego pieczę nad Fundacją Czesława Miłosza w Szetejniach - w przeważającej większości sytuują Miłosza i jego dorobek w kontekście kultury, piśmiennictwa i historii Litwy ${ }^{7}$. Wśród publikacji naukowych w języku litewskim nie ma dotąd prac poświęconych Traktatowi poetyckiemu; można się jednak spodziewać, że po wydaniu litewskiego przekładu pojawią się także jego interpretacje autorstwa litewskich literaturoznawców.

Giedroyc, Czesław Miłosz, Laiškai, t. 1-3, tłum. Kazys Uscila, oprac. M. Kornat, 2010-2017; Grįzimai Lietuvon, tłum. Kazys Uscila et al., 2011.

5 Zob. B. Kalęba, oprac., 2020: Bibliografia przedmiotowa Czesława Miłosza w języku litewskim. W: A. Fiut, E. Pasierski, oprac. S. Bill et al., współpr.: Czesław Miłosz. Bibliografia przedmiotowa 1932-2020. Wybór. Kraków, Wydawnictwo Literackie.

6 Za informacje o obecności twórczości Miłosza w szkołach litewskich i polskich w Litwie dziękuję literaturoznawczyni Brigicie Speičytè.

7 Obszerny wybór literatury przedmiotu można znaleźć w: B. Kalęba, oprac., 2020: Bibliografia przedmiotowa Czesława Miłosza w języku litewskim..., s. 661-678. 
Wiersze zawarte $\mathrm{w}$ tej książce nie zostały przełożone na język „obcy”.

Przecież ten język słyszałem naokoło siebie w dzieciństwie.

Czesław Miłosz (1955) ${ }^{8}$

Szukając początków recepcji twórczości Czesława Miłosza wśród czytelników litewskojęzycznych, trzeba się cofnąć - i to głęboko - w XX wiek. W Litwie sowieckiej zaczęto poetę ledwie wzmiankować po tym, jak otrzymał Nagrodę Nobla (w dwóch wydaniach encyklopedii powszechnej), choć jego nazwisko i w jakimś stopniu - twórczość były znane już wcześniej w Związku Radzieckim (na przykład w latach 60. w kręgach towarzyskich Josifa Brodskiego i Tomasa Venclovy; Miłosza czytano wówczas w oryginale, dzięki wydawnictwom przemycanym z Zachodu i z Polski). Sytuacja po drugiej stronie żelaznej kurtyny wyglądała - rzecz jasna - inaczej. Miłosz w Ameryce utrzymywał kontakty z Litwinami, przede wszystkim z liberalną inteligencją z organizacji Santara-Šviesa ${ }^{9}$. Poświęcone mu publikacje ukazywały się od lat 60. na łamach redagowanych przez członków Santary-Šviesy miesięczników „Metmenys” (Chicago) i „Akiračiai” (Chicago) oraz w czasopiśmie „Aidai” (Nowy Jork), kojarzonym przede wszystkim z tradycjami przedwojennej litewskiej inteligencji katolickiej ${ }^{10}$. Niewątpliwie jednak wśród litewskich powojennych „miłoszianów” najważniejszą i najciekawszą publikacją jest wydany jeszcze wcześniej, bo w połowie lat 50., wybór wierszy z tomów Trzy zimy, Ocalenie i Światło dzienne w przekładzie na język litewski Epochos sąmoningumo poezija (pol. Poezja samoświadomości epoki) ${ }^{11}$. Ukazał się on jako pierwszy tom projektowanej serii wydawniczej magazynu „Literatūros lankai” (Baltimore i Buenos Aires, 1952-1959), z którym byli związani między innymi późniejsi działacze Santary-Šviesy i który współtworzyli literaci (wśród nich przede wszystkim poeci) określani jako žemininkai („,zie-

8 C. Miłosz, 2014: Przedmowa [do litewskiego wyboru wierszy Miłosza Epochos samoningumo poezija (Buenos Aires 1955)]. „Kwartalnik Artystyczny”, nr 2 (82), s. 22.

9 V. Daujotyte, M. Kvietkauskas, 2014: Litewskie konteksty Czesława Miłosza. Monografia. J. Tabor, tłum. Sejny, Fundacja Pogranicze, s. 344-359.

10 Zob. bibliografię zawartości „Metmenys”: https://www.epaveldas.lt/vbspi/biDetails. do?biRecordId=39620 [dostęp: 5.08.2021]; „Akiračiai”: I. Poderienè, E. Montvilienė, R. Raišytè, 2006: „Akiračiu”” bibliografija. Vilnius, Versus aureus oraz na stronie „Aidai": http://aidai.eu/index.php?option=com_content\&view=article\&id=1576:m\&cati $\mathrm{d}=142$ :asmenvardi-rodykl-\&Itemid=166 (hasło: Milosz Czeslaw) [dostęp: 16.02.2021].

11 C. Miłosz, 1955: Epochos sąmoningumo poezija. Su autoriaus įvadiniu žodžiu, vertė ir redagavo J. Kèkštas, užsklandą parašė A. Nyka-Niliūnas. Buenos Aires, Literatūros lankai. 
mianie", poeci ziemi) bądź žemininkai-lankininkai ${ }^{12}$. Ambicją twórców tego czasopisma było włączenie literatury litewskiej w nurt literatury światowej, dlatego na jego łamach sporo miejsca poświęcano przekładom literackim. Wśród nich - i to już od pierwszego numeru - można znaleźć przekłady wierszy Miłosza. Ich autorem jest znajomy noblisty, mieszkający w okresie międzywojennym w polskim Wilnie, a w latach 50. w Argentynie - poeta litewski Juozas Kèkštas, wówczas redaktor „Literatūros lankai” ${ }^{31}$. Warto od razu zaznaczyć, że we wspomnianym pierwszym numerze magazynu ukazało się tłumaczenie wierszy Przedmowa z tomu Ocalenie oraz Hymn ze zbioru Trzy zimy (przedr. w tomie Ocalenie) ${ }^{14}$.

Sam Miłosz opatrzył litewski wybór swych wierszy przedmową (jest w znacznej części autobiograficzna; wiele w niej odwołań do kraju lat dziecinnych, przez co może być czytana jako autokomentarz do Doliny Issy) ${ }^{15}$, natomiast posłowie napisał jeden z najwybitniejszych poetów współredagujących „Literatūros lankai", Alfonsas Nyka-Niliūnas. W tekście tym znajduje się następujący passus:

Wyrzekając się niepotrzebnego efekciarstwa („zrozum tę mowę prostą”) oraz wybierając nie „książęcych faworytów” (poezję na służbie polityki), ani nie „turniej w gronie Klubu Esperantystów" (poezję ars gratia artis), tylko drogę poezji, która samą sobą przynosi ocalenie, Czesław Miłosz w pewnym sensie zajął stanowisko moralisty, zgodnie z którym słowo musi mieć siłę do zmieniania rzeczywistości i musi być gotowe umrzeć za swoją prawdę, to znaczy musi być jednorazowe jednorazowe w swej epoce i wielkim kole Czasu ${ }^{16}$.

We fragmencie tym jak $\mathrm{w}$ soczewce skupiają się postulaty podnoszone także w gronie žemininkai-lankininkai: zapotrzebowanie na nową dykcję

12 Na ten temat zob. M. Kasner, 1999: Czesław Miłosz i „Literatūros lankai”(1952-1959). „Tygiel Kultury”, nr 10-12, s. 146-154; B. Kalęba, 2014b: Nota. „Kwartalnik Artystyczny", nr 2 (82), s. 25-26; V. Daujotytė, M. Kvietkauskas, 2014: Litewskie konteksty Czesława Miłosza..., s. 306-343; B. Kalęba, 2014a: Czesław Miłosz i litewscy „Kolumbowie”. Przyczynek do jeszcze jednej biografii równoległej. „Wielogłos”, nr 2 (20), s. $65-80$.

13 Na temat znajomości Czesława Miłosza z Juozasem Kèkštasem zob. V. Daujotyté, M. Kvietkauskas, 2014: Litewskie konteksty Czesława Miłosza..., passim.

14 C. Miłosz, 1952: Ľžanga; Himnas. J. Kèkštas, tłum. „Literatūros lankai”, nr 1, s. 12.

15 Skany polskojęzycznego oryginału przedmowy przechowywanego $\mathrm{w}$ archiwum Czesława Miłosza w Beinecke Library zostały opublikowane w: C. Miłosz, 2014: Przedmowa..., s. 13-24.

16 A. Nyka-Niliūnas, 1955: [Posłowie]. W: C. Miłosz: Epochos..., s. 88. Dalej cytaty $\mathrm{z}$ tego posłowia oznaczam skrótem $\mathrm{N}$, po którym podaję numer strony. Wszystkie cytaty z języka litewskiego, o ile nie zaznaczono inaczej, podaję w moim przekładzie B.K. „Książęcy faworyci” oraz „turniej w gronie Klubu Esperantystów” to przytoczenia z przedmowy Miłosza do Epochos... 
poetycką $^{17}$ - taką, jaka umożliwi dawanie świadectwa powojennej rzeczywistości; odrzucenie rozumienia poezji jako służącej politycznym - a więc zwykle doraźnym - celom, a poetów jako ludzi pióra szukających poklasku, klientów tych, którzy mają władzę; jak również zanegowanie wizji poezji jako sztuki czystej, rozumianej przez nich jako sztuka nierealistyczna i niepotrzebująca odbiorców, nieszukająca zrozumienia. Rzecz jasna, kluczowe jest tu słowo „ocalenie” - dodajmy, chodzi o to, aby poezja była zdolna zmieniać rzeczywistość po to, by ocalić człowieczeństwo, a więc w tej interpretacji przede wszystkim kulturę. Jak pisał Nyka-Niliūnas, poezja Miłosza to „głos człowieka wolnego, który poszukuje drugiego człowieka, oraz [...] protest przeciwko poświęceniu człowieka i kultury bożkom propagandy” (N, 89); to „poezja miasta oblężonego przez barbarzyńców. Jej ideowy lejtmotyw - tak przerażający dla ówczesnego społeczeństwa - można scharakteryzować następująco: za murami miasta stoją barbarzyńcy, co dla nas - mieszkańców miasta - jest równoznaczne z pytaniem, kiedy oni tu wkroczą, a my, wraz z naszą kulturą, staniemy się już tylko legendą przeszłości?” (N, 89). Owi barbarzyńcy to Sowieci, którzy stali „u bram” Europy pojmowanej jako wspólnota kulturowa. Oznacza to, iż litewscy pisarze emigracyjni z kręgu žemininkai-lankininkai byli skłonni czytać Miłosza jako poetę, który jest w stanie wyrazić ich własne doświadczenia - Wschodnioeuropejczyków wygnanych z ojczyzny. Drogą życiową części ówczesnej inteligencji litewskiej była emigracja, najczęściej do obu Ameryk, podejmowana między rokiem 1944 a pierwszą połową lat 50. w obliczu sowieckiej okupacji, rozumianej nie tylko jako zagrożenie polityczne czy ekonomiczne, ale wręcz cywilizacyjne. Warto podkreślić, że istotne było dla nich doświadczenie wygnania nie wyłącznie jako emigracji, lecz także jako imigracji. Jednym z najważniejszych tematów w twórczości žemininkai-lankininkai są sposoby werbalizacji doświadczenia okropieństw wojny oznaczającej kres pewnego porządku opartego na określonych wartościach, a zarazem początek nowej niewoli; wykorzenienie i następnie możliwe (lub niemożliwe) zakorzenienie człowieka ukształtowanego we wschodniej Europie - będącej wszakże częścią większej całości, to znaczy Europy o kulturze łacińskiej — na nowej ziemi, w Ameryce. W 1951 roku w Los Angeles ukazał się pierwszy zbiór wierszy poetów współtworzącyh później „Literatūros lankai”, zatytułowany Žemé (pol. Ziemia). We wstępie do tej

17 Algirdas Julius Greimas w eseistycznej recenzji Epochos... pisał: „Dla kogo pisać wiersze? Dla kogo w ogóle pisać? To pytanie dręczy nie tylko Miłosza. Nowoczesna poezja unicestwiła literaturę jako źródło zabawy i przyjemności. Jej pretensje: stworzyć nowy język, język prawdy, gdzie słowa przestałyby być narzędziem komunikacji społecznej, ale przylgnęlyby do rzeczy, do wskazanej palcem istoty”. A.J. Greimas, 1959: Sąmoné ir sąžiné (Cz. Miloszo poezijos vértimus perskaičius). „Literatūros lankai”, nr 8, s. 9. 
publikacji litewski filozof Juozas Girnius, przedstawiciel teistycznego egzystencjalizmu, pisał:

Oto kierunek naszej najnowszej poezji [...]: Z i e $\mathrm{m}$ i a. [...] w centrum tej poezji stoi problem metafizycznego losu człowieka. [...] To poezja sensu ludzkiej egzystencji na ziemi [wyróżnienia-J.G.] ${ }^{18}$.

Zaś Greimas w przywołanym już eseju recenzyjnym o twórczości Miłosza snuł rozważania, cytując między innymi wiersz Pieśń z tomu Trzy zimy:

Poezja samoświadomości epoki. Transformer l’expérience en conscience: Malraux. [...]

Świadomość to stygmat naszej epoki, jej wielkość i marność. [...] Transformer l’expérience en conscience! Doświadczenie przekuwane w świadomość; jednak żadna dialektyka nie skieruje snopu światła świadomości z powrotem ku konkretnemu ludzkiemu bytowi. „Klub esperantystów” - mówi Cz. Miłosz, który sam dobrze wie, co znaczą zawroty głowy od kontaktów z wyższymi sferami.

- Ziemio, nie opuszczaj mnie, — modli się Anna. A chór, mądrość starców, głos ludzkiej wspólnoty, potwierdza:

Radość wszelka jest z ziemi, nie masz prócz ziemi wesela,

człowiek jest dany ziemi, niech ziemi tylko pożąda.

$(\text { Pieśń })^{19}$

Oprócz kilku wierszy Miłosza w „Literatūros lankai” (1955, nr 6) ukazały się także wyimki ze Zdobycia władzy poświęcone powstaniu warszawskiemu ${ }^{20}$. Warto zwrócić uwagę, że znalazł się wśród nich fragment, w którym dwoje bohaterów powieści, Magda i Foka, podczas rozstrzeliwania pacjentów szpitala psychiatrycznego trzyma się za ręce i dzięki temu zachowuje poczucie człowieczeństwa. Dotyk żywego ciała (bądź to człowieka, bądź - właśnie - ziemi) jest jedną z dróg do ocalenia, co jest obecne w twórczości i Miłosza, i pisarzy z grona žemininkai-lankininkai ${ }^{21}$.

Tak więc, nie umniejszając wagi oraz trafności opinii cytowanych eseistów - interpretatorów litewskich przekładów wierszy Miłosza, wydaje się, że najważniejszym kluczem otwierającym interpretacyjnie twórczość noblisty dla ówczesnych litewskojęzycznych czytelników było słowo „ocalenie”. Nieprzypadkowo

18 J. Girnius, 1991: Žmogaus prasmés žemejje poezija. W: K. Bradūnas, red.: Žemè. Naujosios lietuviu poezijos antologija. J. Girnius, przedm. Vilnius, Vyturys, s. 37 [reprint wydania: Los Angeles 1951].

19 A.J. Greimas, 1959: Sąmonè ir sąžiné..., s. 9.

20 C. Milosz, 1955: Nevilties apgultieji. Fragmentai iš romano „Valdžios paemimas“.

J. Kèkštas, tłum. „Literatūros lankai”, nr 6, s. 10-12.

21 Więcej na ten temat zob. B. Kalęba, 2014b: Nota... 
Nyka-Niliūnas opatrzył posłowie do Poezji samoświadomości epoki mottem z przywoływanego już wiersza Przedmowa z tomu Ocalenie („Czym jest poezja, która nie ocala / Narodów ani ludzi?").

W „Literatūros lankai” ukazał się także - zdaje się, że niepublikowany nigdzie indziej - bardzo ostry szkic Miłosza o instrumentalizacji postaci i dzieła Adama Mickiewicza przez Polaków ${ }^{22}$. Nie był to pierwszy przypadek współpracy Miłosza z czasopismami litewskimi. Dość wspomnieć o publikacji w 1940 roku jego dwóch esejów wojennych na łamach tygodnika o proweniencji międzywojennej „Naujoji Romuva”. Jeden z nich jest poświęcony Oskarowi Miłoszowi, prezentowanemu przez autora jako myśliciel, który przeczuł upadek kultury europejskiej, ale który także ukazał drogi do jej odrodzenia (a może ocalenia?). Drugi esej to rozważania o wojnie jako niszczącej sile, która wyznacza kres danego projektu polityczno-społecznego, a zarazem oznacza konieczność odbudowy, wypracowania nowych form współżycia międzyludzkiego, także nowych kategorii politycznych i społecznych, po to, by ludzki świat mógł doświadczyć, przynajmniej w jakimś stopniu, ocalenia ${ }^{23}$. Jak sądzę, można powiedzieć, że posłowie Nyki-Niliūnasa do litewskiego tomu Miłosza mogłoby być nie tylko komentarzem do zawartych tam wierszy autora Ocalenia, ale i do - napisanego nieco później - Traktatu poetyckiego oraz, szerzej, całej twórczości Miłosza powstałej w latach 50. Zacytuję jeszcze wyimek z krótkiego szkicu tego litewskiego poety, dobrze podsumowujący, jak mi się zdaje, przedstawione rozważania, a zarazem pozwalający w dalszej części artykułu przywołać tłumacza Traktatu poetyckiego na język litewski - Tomasa Venclovę. Jak napisał Nyka-Niliūnas,

[p]oezja Czesława Miłosza ogłasza koniec świata i kres ideałów tegoż [przedwojennego - B.K.] społeczeństwa, a także konieczność stawienia czoła z otwartą przyłbicą człowiekowi i rzeczywistości - takim, jakimi faktycznie są $(\mathrm{N}, 87)$.

22 C. Milosz, 1959: Mickevičius ir istorijos paradoksai. J. Kèkštas, tłum. „Literatūros lankai", nr 8, s. 2.

23 C. Miłosz, 2018: Idee O. Miłosza oraz Rozmyślania o czasie pożogi. B. Kalęba, tłum. W: Idem: W cieniu totalitaryzmów. Publicystyka rozproszona z lat 1945-1952 oraz teksty z okresu II wojny światowej. A. Fiut et al., red. Kraków, Wydawnictwo Literackie. 
$* \quad *$

Najważniejszym celem poezji jest pokonać rozpacz, przezwyciężyć entropię.

Tomas Venclova (1978) ${ }^{24}$

Dlaczego tyle uwagi poświęciłam litewskiej recepcji twórczości Czesława Miłosza w latach 50. XX wieku? Powodów jest kilka. Przede wszystkim to w tamtych latach powstał Traktat poetycki w ostatecznym kształcie (warto pamiętać również o Dolinie Issy, szczególnie wyróżnionej przez jej autora w przedmowie do Poezji samoświadomości epoki, a także o Zdobyciu władzy - utworze, który zainteresował redaktorów „Literatūros lankai”). Także dlatego że - jak wspomniałam - sam Miłosz miał związki z kręgiem autorów „Literatūros lankai”, a następnie, podobnie jak Tomas Venclova, ze środowiskiem Santara-Šviesa. Nie bez znaczenia wydaje się też to, iż emigracyjne publikacje powojenne to zapewne dość oczywisty kontekst dla recepcji Traktatu poetyckiego wśród czytelników litewskojęzycznych. Wreszcie dlatego że jestem zwolenniczką takiego rozumienia relacji pomiędzy tekstem wyjściowym a jego przekładem na inny język oraz między autorem tekstu tłumaczonego a autorem przekładu, które nakazuje dokonywać odczytania utworu literackiego - tłumaczenia $\mathrm{z}$ innego języka, w pierwszym rzędzie mając na uwadze kontekst biografii autora utworu określanego jako przekład oraz literatury i sytuacji pozaliterackiej w kulturze języka przekładu ${ }^{25}$. Przyjęcie takiego założenia prowadzi do wniosku, że dla zrozumienia możliwych stylów odbioru litewskiego przekładu Traktatu poetyckiego Czesława Miłosza ważny jest nie tylko kontekst litewski ostatnich kilkudziesięciu lat (na wychodźstwie i w kraju), lecz także biografia i twórczość tłumacza, który jest również rzecznikiem oraz interpretatorem bądź przynajmniej komentatorem tłumaczonej przez siebie literatury i jej autorów. Od razu dodam, że Venclova nie unika pełnienia wszystkich wspomnianych tu ról.

O relacjach Czesława Miłosza i Tomasa Venclovy wiemy dużo ${ }^{26}$. Nie jest tajemnicą, że to między innymi dzięki zabiegom Miłosza ten litewski poeta,

24 T. Venclova, 2011: Rozpacz i łaska. W: C. Miłosz, T. Venclova: Powroty do Litwy. B. Toruńczyk, wyb., oprac. M. Nowak-Rogoziński, współpr. Warszawa, Fundacja Zeszytów Literackich, s. 41. Dalej cytaty z tego eseju oznaczam skrótem RiŁ, po którym podaję numer strony.

25 Obszerne informacje o obcojęzycznej i polskojęzycznej literaturze przedmiotu można znaleźć w artykule: J. Kita-Huber, R. Makarska, 2020: Wyjść tłumaczowi naprzeciw. Wprowadzenie. W: Eaedem, red.: Wyjść tłumaczowi naprzeciw. Miejsce tłumacza w najnowszych badaniach translatologicznych. Kraków, TAiWPN Universitas, s. 5-19.

26 Spośród najnowszych publikacji zob. np.: T. Venclova, 2016: Magnetyczna Pótnoc. E. Hinsey, rozm. M. Ochab, tłum. Warszawa, Fundacja Zeszytów Literackich, passim; A. Fiut, 2017: Czesław Miłosz i Tomas Venclova. „Zeszyty Literackie”, nr 3 (139), s. 111-118. 
tłumacz i literaturoznawca został zaproszony na wykłady gościnne na Uniwersytet Kalifornijski w Berkeley, co okazało się początkiem jego trwającej czterdzieści lat emigracji. Wiemy także, że to właśnie Miłosz jest autorem pierwszego przekładu wiersza Venclovy (Rozmowa $w$ zimie) na język polski. Do lektur obowiązkowych Polaków (i nie tylko Polaków) zainteresowanych Litwą i stosunkami polsko-litewskimi w XX wieku należy Miłosza i Venclovy Dialog o Wilnie. Z kolei Venclova jest niewątpliwie jednym z najważniejszych współczesnych tłumaczy oraz komentatorów poezji Miłosza w języku litewskim ${ }^{27}$. Jest także autorem kilku poświęconych nobliście szkiców, które były publikowane między innymi po angielsku, rosyjsku, litewsku i oczywiście po polsku.

Pierwszy z tych tekstów został wydany w 1978 roku, a więc rok po przyjeździe Venclovy do USA, pod tytułem Czesław Miłosz. Despair and Grace na łamach „World Literature Today”28. Łączy on w sobie przynajmniej trzy perspektywy: samego Venclovy, który nie stroni od odniesień do własnej biografii, litewską czy może raczej wschodnioeuropejską oraz amerykańską, którą można nazwać po prostu światową lub też globalną. Są one ze sobą nierozerwalnie splecione, co dobrze ukazuje następujący przykład: perspektywę indywidualną ilustruje lektura Rodzinnej Europy przemyconej do sowieckiej Litwy, wschodnioeuropejską - recepcja wierszy Miłosza jako szczególnego rodzaju kodu, a więc podobna do recepcji choćby Osipa Mandelsztama bądź Anny Achmatowej w Rosji, globalną - poemat Gdzie wschodzi słońce i kędy zapada, stanowiący przykład poszukiwań nowej formy poetyckiej. Jako szczególnie istotne utwory Miłosza wymienia tu Venclova także Zniewolony umysł oraz Doline Issy, jak sądzę, zwracając w ten sposób uwagę na znaczenie splotu wspomnianych trzech perspektyw (człowieka - indywiduum, Wschodnioeuropejczyka w Ameryce) również dla samego Miłosza. Można więc powiedzieć, że oto poeta, emigrant $z$ Wilna i wschodniej (komunistycznej) Europy do Stanów Zjednoczonych Ameryki przygląda się starszemu poecie, również emigrantowi z Wilna ${ }^{29}$ i wschodniej (komunistycznej) Europy do Stanów Zjednoczonych Ameryki. Oznacza to między innymi, że dzięki pojmowaniu tego, co ma do powiedzenia ów starszy poeta, poeta młodszy lepiej czy też w większym stopniu pojmuje siebie samego, własne doświadczenie. Wydaje mi się, iż taki styl odbioru twórczości (ale i losów życiowych) Miłosza, zaświadczony piórem Venclovy, jest niedaleki temu, co sprawiło, że pisarstwo noblisty okazało się aktualne

27 Pełen wykaz przekładów do 2011 roku: T. Venclova, 2012: Bibliografijos rodyklè. Bibliographic index. Bibliografia 1956-2011. Vilnius, LNMB.

28 Ibidem, s. 186. W Polsce ten tekst był publikowany pod tytułem Rozpacz $i$ łaska.

29 W dialogach i innych szkicach Miłosza i Venclovy wspólne - choć już przecież inne miasto Wilno/Vilnius jest zwykle pierwszym, co ich łączy i co pozwala nawiązać nić porozumienia. 
$\mathrm{i}$ istotne dla pisarzy z pokolenia žemininkai-lankininkai. Oto cytat ze szkicu Rozpacz i łaska:

Poezję powinno się pisać tak, by wychodziła naprzeciw zarówno katastrofom niszczącym kultury, jak i owej frapującej zdolności kultur do przetrwania. Pisać tak można tylko wówczas, jeśli żywi się prawdziwe zrozumienie dla różnych kultur, co jest nierozłącznie związane z życzliwością dla ludzi (Riє, 37).

Widać, że zarówno wspominani tu litewscy pisarze emigracyjni, jak i autor Rozpaczy i łaski podobnie rozumieją Miłoszową koncepcję poezji - poezji ocalającej. Dodać od razu można, że słowa o „frapującej zdolności kultur do przetrwania" są typowe dla myślenia Venclovy o kulturze (dobrym choć oczywiście nie jedynym tego przykładem jest esej - notabene z roku 1979 - o Uniwersytecie Wileńskim pt. Lata wytrwatości ${ }^{30}$ ). Nietrudno zauważyć, że choć nie wzmiankuje się tu Traktatu poetyckiego, mowa o jednym z tematów tego utworu. Wśród zawartych w Rozpaczy i łasce spostrzeżeń o twórczości Miłosza można znaleźć więcej takich, które są bliskie interpretacjom litewskim z lat 50. Dotyczą one choćby wyboru drogi poetyckiej (tak w znaczeniu estetycznym, jak i społecznym). I ponownie przypominają uwagi Nyki-Niliūnasa, Greimasa czy Girniusa, tyle że świadczą, jak mi się wydaje, o lepszym rozeznaniu Venclovy w twórczości Miłosza, w tym o przemyśleniu przez niego właśnie Traktatu poetyckiego:

Jak wiadomo, Miłosz poszedł własną drogą, mimo iż żył w kręgu oddziaływania kilku silnie zakorzenionych tradycji poetyckich. Zazwyczaj wymienia się tu skamandrytów i awangardzistów. [...] Tym, co zawsze wyróżniało Miłosza, była głęboka życzliwość dla ludzi i umiejętność wsłuchania się w clamor temporum (a można było usłyszeć niemal wszystko, co później się wydarzyło). Zawsze był antyformalistą i moralistą. Formalizm, kreowanie specjalnego języka dla wtajemniczonych (który jeśli się bliżej przyjrzeć, często okazuje się prostackim esperanto) jest bodaj najsilniejszą pokusą współczesnej poezji. Miłosz powiedział kiedyś, że totalitaryzm gotów jest pozwolić na szaleństwa awangardy, byle tylko poeta był czymś zajęty i nie próbował zmieniać rzeczywistości. Co prawda w Rosji (a w swoim czasie także w Niemczech) totalitarne państwo jeszcze do tego nie dojrzało, ale stosuje tę zasadę w wielu krajach Europy Wschodniej, być może także we współczesnej Litwie. A przecież Miłosz zawsze chciał, i chce także teraz, wpływać na rzeczywistość wierszem, chce odnaleźć w niej swoje miejsce, ale w żadnej mierze nie chce być sługą czasów, w których przyszło mu żyć. Poeta jest wyrazicielem swojej epoki, jako że jest wyrazicielem jej języka,

30 T. Venclova, 1983: Lata wytrwałości. A.A. tłum. „Zeszyty Literackie”, nr 4 (8). 
epoka i język „myślą przez poetę”; jednak ta myśl z kolei powinna wpływać na epokę i język; i dlatego są tu konieczne wyjątkowa trzeźwość spojrzenia, uczciwość i samokontrola (RiŁ, 38-39).

Podobnie jak žemininkai-lankininkai, Venclova nazywa Miłosza moralistą i podobnie jak oni uważa, że poezja nie może być ars gratia artis. Zwłaszcza antyformalizm jest zakorzeniony w poglądach Venclovy na poezję i szerzej literaturę. Nie raz i nie dwa pisał on tak: „[D]obra poezja — zwłaszcza w naszych czasach - nie powinna uciekać przed historią, chować się pod osłoną anarchicznego surrealizmu lub czysto lingwistycznej zabawy"31. Zresztą Venclova zwraca szczególną uwagę na to, że według Miłosza w twórczości literackiej ma znaleźć odbicie obiektywnie istniejąca hierarchia wartości ${ }^{32}$, co nie jest łatwe, ponieważ wymaga to niepoddawania się złu oraz umiejętności uniknięcia zgniecenia przez tryby historii, która jest domeną chaosu (RiŁ, 37-39).

Tomas Venclova napisał jeszcze jeden obszerny szkic poświęcony twórczości Czesława Miłosza, przede wszystkim jego poglądom na to, czym i jaka winna być poezja. Ukazał się on pod tytułem Poezija kaip atpirkimas (pol. tytuł Poezja jako pokuta) w 1983 roku na łamach „Akiračiai”33. Jest to esej recenzyjny o zbiorze Świadectwo poezji. W porównaniu ze szkicem Rozpacz i łaska, w tym tekście autor - co zrozumiałe - skupia się w większym stopniu na rozważaniach o naturze poezji i kultury, sytuując twórczość Miłosza w kontekście literatury europejskiej. Istotne jest to, że litewski poeta i akademik porównuje Miłosza i do autora z kręgu anglosaskiego („zachodniego”), i rosyjskojęzycznego („wschodniego”), co jest poszerzeniem i uzupełnieniem perspektywy znanej z omawianego tekstu z 1978 roku:

To, co mógłby ktoś nazwać konserwatyzmem Miłosza, jest nade wszystko dążeniem, aby nie poddać się prądowi rzeki Heraklita. Miłosz interesuje się strukturami głębokimi ludzkiego doświadczenia, językiem kultury określającym jej funkcjonowanie w czasie - jej mowę. Jeśli jest podatny na nostalgię, to jest to tęsknota nie za utraconą ojczyzną czy nawet dzieciństwem, ale za utraconą skalą wartości, za samą kategorią wartości, za kulturą, za językiem. Nietrudno wykryć niejakie podobieństwo między Miłoszem a Eliotem, którego tłumaczył w okupacyjnym podziemiu. (Każdy, komu znane są losy Wschodniej Europy, wspomniałby w tym kontekście jeszcze jednego poetę - Osipa Mandelsztama) (PjP, 95).

31 T. Venclova, 2013: Lietuviu poezija. W: Idem: Pertrūkis tikroveje. Straipsniai apie literatūra ir kultūra. Vilnius, LLTI, s. 140.

32 T. Venclova, 2011: Poezja jako pokuta. W: C. Miłosz, T. Venclova: Powroty do Litwy..., s. 94. Dalej cytaty z tego szkicu oznaczam skrótem PjP, po którym podaję numer strony.

33 T. Venclova, 2012: Bibliografijos..., s. 186. 
Cytat ten mógłby stanowić dopowiedzenie do krótkiego komentarza Nyki-Niliūnasa opublikowanego wraz z tomem Poezja samoświadomości epoki; myślę przede wszystkim o słowach o tęsknocie za „utraconą [...] kategorią wartości, za kulturą, za językiem”. Istotną różnicą czy też nowością, w której wciąż jednak zdaje się pobrzmiewać echo rozważań pisarzy žemininkai-lankininkai, jest podjęta przez Venclovę próba scharakteryzowania poezji tworzonej w Europie Wschodniej w kontraście do poezji Zachodu:

Poezja Europy Wschodniej bez wątpienia znajduje się bliżej bieguna realistycznego. Każdy, kto porównał poezję zachodnią z autentyczną poezją pisaną w krajach totalitarnych, doświadczył zapewne osobliwego poczucia, że nie są to warianty tej samej sztuki, lecz raczej dwa odmienne rodzaje sztuki. Co na Zachodzie jest zaledwie rozrywką lub w najlepszym wypadku zwierzeniem z freudowskiej kozetki, na Wschodzie jest wciąż jeszcze sprawą życia, a nierzadko i śmierci (PjP, 98).

Venclova posługuje się słowem realizm (tu chyba w znaczeniu potocznym czy raczej intuicyjnym), łączonym przez niego nie tylko z kwestiami życia i śmierci, lecz także najdosłowniej z życiem i śmiercią - co zresztą, moim zdaniem, tłumaczy niechęć tak Miłosza, jak i Venclovy do posługiwania się modnymi wówczas koncepcjami śmierci autora i śmierci podmiotu. Zmaganie się, wypracowywanie nowej dykcji poetyckiej, która będzie w stanie dawać świadectwo takiemu (jednostkowemu i międzyludzkiemu) doświadczeniu, patronuje oczywiście Ocaleniu i Światlu dziennemu, jak również Traktatowi poetyckiemu. Nietrudno tu wszak usłyszeć frazę: „Mowa rodzinna niechaj będzie prosta. / Ażeby każdy, kto usłyszy słowo, / Widział jabłonie [...]", przywołującą w pamięci Wstęp do Traktatu poetyckiego i wreszcie cały poemat. Jak mi się wydaje, Venclovy interpretacja wykładów zawartych w Świadectwie poezji daje jedną z możliwych odpowiedzi na pytanie, dlatego pierwsze słowa Traktatu poetyckiego w jego litewskim przekładzie brzmią tak a nie inaczej. Są oczywiście także podpowiedzią, jak czytać wiersze samego Venclovy. Nie ma tu jednak miejsca na lekturę wierszy, które odkrywają swój sens dopiero po uruchomieniu wielu kontekstów oraz odsłonięciu kolejnych warstw znaczeniowych. Dlatego odwołam się raz jeszcze do przywoływanych esejów; oto dłuższy fragment Rozpaczy i łaski:

Poeta jest także strażnikiem tradycji, strażnikiem słowa. Zainteresowanie tradycją i słowem cechowało Miłosza od najwcześniejszych lat, ale stało się nadzwyczaj silne po doświadczeniach wojny, okupacji i pierwszych lat powojennych. Totalitaryzm, również ogólna chaotyczność historii, zagraża przede wszystkim istnieniu ludzkości w czasie; jeśli chcemy mieć przyszłość, musimy mieć przeszłość. Dewastowany (i zdewastowany) świat powinien znaleźć nową integralność w sferze myśli i w poezji. Dlatego właśnie Miłosza interesuje osadzenie 
człowieka w czasie i przestrzeni i stąd właśnie bierze się jego fascynacja „oporną materią", jego rzadka zdolność rozumienia i umiejętność przekazania cech świata niemal w kilku słowach (RiŁ, 39).

Koncepcja chaotyczności historii oraz ocalania świata (chodzi oczywiście o ludzki świat kultury i cywilizacji, a także o mikroświaty poszczególnych ludzi) dzięki formowaniu, lepieniu, a może wydobywaniu rozumnych, komunikowalnych wypowiedzi z „opornej materii” słów łączy Venclovę z jednej strony z Miłoszem, z drugiej zaś z rosyjskimi akmeistami, przede wszystkim z Achmatową i Mandelsztamem. To oni jako pierwsi uczyli litewskiego poetę takiego właśnie rozumienia poezji - jako drogi do pokonania entropii. Należałoby tu wspomnieć o jeszcze jednym zagadnieniu, które również jest obecne, choć może nieszczególnie eksponowane, tak w esejach Venclovy poświęconych Miłoszowi, jak i w Traktacie poetyckim: chodzi o pamięć, która u wszystkich wymienionych poetów jest tak pamięcią jednostkową, jak i pamięcią zbiorową, pamięcią kultury. Obie te pamięci warunkują się wzajemnie. To również jest droga do ocalenia kultury i człowieka, jednostki. W eseju Poezja jako pokuta Venclova pisał:

[D]oświadczenie Miłosza przełamało się przez pryzmat jego osobistej geografii i osobistej historii: „Poznajemy, z litością i grozą, kondycję ludzką nie ogólnie, ale zawsze w odniesieniu do danego miejsca i daty, w tej a nie w innej prowincji, tym a nie innym kraju" (PjP, 92).

Venclova oczywiście ma własną „osobistą historię”, pod pewnymi względami podobną, a pod innymi zupełnie różną niż Czesław Miłosz. Tak samo jak Miłosz uważa on, że doświadczenie historyczne znajduje swój wyraz w poezji za sprawą osobistego doświadczenia i przeżycia (dodajmy, mogą być one zapośredniczone w kulturze). Venclova w słowie od tłumacza do litewskiej edycji Traktatu poetyckiego napisał, że

Często uważany jest [Traktat poetycki - B.K.] za szczytowe osiągnięcie twórczości Czesława Miłosza, jego magnum opus. Słynna amerykańska krytyczka Helen Vendler twierdzi, że jest to jeden z dwóch najwybitniejszych poematów XX wieku - obok Ziemi jałowej Thomasa Stearnsa Eliota. W każdym razie zajmuje szczególne miejsce nie tylko w literaturze polskiej, ale i światowej ${ }^{34}$.

Sądzę, że nieprzypadkowo napisał: „często uważany jest”. Jego zdaniem, Traktat poetycki należy do najważniejszych dzieł Miłosza, tyle że ta „ważność” jest

34 T. Venclova, 2021: Słowo tłumacza do litewskiego czytelnika. B. Piasecka, tłum. W: C. Miłosz: Traktat poetycki..., s. 203. Za udostępnienie makiety książki serdecznie dziękuję dyrektor wydawnictwa Apostrofa, Giedrè Kadžiūlytė. 
przynajmniej dwojakiego rodzaju: chodzi tyleż o osobiste fascynacje literackie tłumacza, co o wagę tego utworu dla literatury światowej. Natomiast gdyby skupić się na osobie tłumacza, należałoby przywołać przede wszystkim wiersz Miłosza Mittelbergheim, o którym Venclova mówił: „Wiele razy w życiu je [linijki wiersza od słów „Ogniu, potęgo, siło” - B.K.] powtarzałem, początkowo tylko na poły świadomie przeczuwając swój los, i później, kiedy już byłem za granicą, kiedy moja sytuacja zaczęła przypominać do pewnego stopnia los Miłosza" ${ }^{\text {"35 }}$. Nieprzypadkowo wiersz Venclowy Święto Dziękczynienia, literacka odpowiedź na ostatni utwór ze zbioru Światło dzienne, otwiera jego pierwszy tom poezji wydany na emigracji ${ }^{36}$. Tak oto relacja między tymi dwoma poetami ze wschodniej Europy, którzy reprezentują różne pokolenia wilnian i różne pokolenia emigrantów, rozpina się pomiędzy osobistym, intymnym doświadczeniem uwewnętrznienia utworu Mittelbergheim, a następnie napisania własnej poetyckiej odpowiedzi na ten wiersz a latami dojrzewania do stworzenia odpowiedzi literackiej (wprawdzie innego rodzaju, ale wciąż własnej) na historiozoficzny poemat Miłosza - litewskiego przekładu Traktatu poetyckiego. Utwór ten, zdaniem tłumacza, jest opowieścią o historii Polski w XX wieku, której perypetie są podobne do doświadczeń Litwy, tak zresztą jak podobne jest doświadczenie poezji polskiej i litewskiej ${ }^{37}$.

Jak mi się wydaje, dla Tomasa Venclovy w ostatnich latach szczególnie interesująca może być część IV poematu, Natura, kończąca się wizją powrotu ze świata natury do świata historii, na ojczysty kontynent. Można powiedzieć, że ponownie - jak niegdyś w przypadku wiersza Mittelbergheim - Miłoszowy Traktat poetycki dał Venclovie przeczucie wspólnoty losów. Już w 1978 roku litewski poeta pisał tak:

Przykład Czesława Miłosza budzi nadzieję. Dokonał on czegoś, co teraz winno stać się udziałem wychodźców z Europy Wschodniej - pozostał wierny sobie i dotarł do ojczyzny. To zaś, co udało się jednemu człowiekowi, może stać się udziałem wielu (RiŁ, 43).

Venclova wówczas miał, rzecz jasna, na myśli powrót Miłosza pod postacią twórczości, która była już wtedy w Polsce, jak pisałam wcześniej, rodzajem swoistego kodu opozycji czy oporu wobec oficjalnych, regulowanych form życia społecznego. Podobnie jednak jak wiele lat później Miłosz powrócił do Polski i zamieszkał w Krakowie, tak też Venclova po czterdziestu latach emigracji powrócił do Litwy — od 2019 roku mieszka w Wilnie. Wydaje się, że nie był i nadal nie

35 T. Venclova, 2016: Magnetyczna Pótnoc..., s. 391.

36 T. Venclova, 1990: Tankejjanti šviesa. Chicago, AMKLF, s. 13-14.

37 T. Venclova, 2021: Stowo tłumacza..., s. 205.

\begin{tabular}{l|l|} 
PLS.2021.11.01.11 & S. 15 z 20
\end{tabular} 
jest to powrót łatwy. Tomas Venclova nie przestał być aktywnym komentatorem litewskiej rzeczywistości społecznej, zwłaszcza oficjalnej polityki historycznej, a także pro- i antyeuropejskich (antyunijnych, antyglobalizacyjnych) nurtów ideowych. Kilka miesięcy temu opublikował głośny artykuł recenzyjny o edycji dzienników litewskiego pisarza i działacza komunistycznego Juozasa Baltušisa, w którym wykazuje ideową bliskość litewskiej wersji komunizmu i współczesnej litewskiej skrajnej prawicy ${ }^{38}$. Trudno nie odnieść wrażenia, że mamy tu do czynienia z ciągiem dalszym rozważań ujętych we frazie: „Niech tutaj będzie wreszcie powiedziane: / jest ONR-u spadkobiercą Partia" ${ }^{39}$. Venclova po powrocie do Litwy - i wiele lat po pierwszej lekturze Traktatu poetyckiego - jest więc nie tylko tłumaczem kolejnego wybitnego utworu Czesława Miłosza i podobnie jak žemininkai-lankininkai jego komentatorem w kontekście litewskim, lecz także w jakiejś mierze kontynuatorem namysłu Miłosza nad ludzkim światem w skali osobistej, wschodnioeuropejskiej i europejskiej. W 1978 roku, w eseju Rozpacz $i$ łaska, Venclova cytował Dzwony w zimie z tomu Gdzie wschodzi słońce $i$ kędy zapada: mówiąc o wschodniej Europie, pisał o „zaprzeszłym czasie krajów niedokonanych" (RiŁ, 43). Trudno oprzeć się wrażeniu, że litewski czytelnik otrzymuje przekład Traktatu poetyckiego Czesława Miłosza w chwili, gdy niektórzy znów widzą, jak gdzieś na horyzoncie

Przechadza się Duch Dziejów, poświstuje.

Lubi te kraje obmyte potopem,

Bezkształtne odtąd i odtąd gotowe ${ }^{40}$.

Co pod piórem Tomasa Venclovy brzmi:

Matome vaikštant Istorijos Dvasią.

Švilpauja. Mègsta tvano apiplautą

Beformę šali, kur leidžiama viskas ${ }^{41}$,

a znaczy dosłownie: „Widzimy, jak przechadza się Duch Dziejów. / Gwiżdże. Lubi obmyty potopem / Bezkształtny kraj, gdzie wolno wszystko”.

38 Polski przekład ukazał się jako: T. Venclova, 2020: Dajesz, Baltušis! Patriota na sterydach. B. Kalęba, tłum. „Gazeta Wyborcza”, 24.12.2020. Dostępne w Internecie: https:// wyborcza.pl/magazyn/7,124059,26632612,dajesz-baltusis-patriota-na-sterydach.html [dostęp: 5.08.2021].

39 C. Miłosz, 2001: Traktat poetycki..., s. 43.

40 Ibidem, s. 55-56.

41 C. Miłosz, 2021: Traktat poetycki..., s. 47. 


\section{Literatura}

Daujotytė V., Kvietkauskas M., 2014: Litewskie konteksty Czesława Miłosza. Monografia. J. Tabor, tłum. Sejny, Fundacja Pogranicze.

Girnius J., 1991: Žmogaus prasmès žemèje poezija. W: K. Bradūnas, red.: Žemè. Naujosios lietuviu poezijos antologija. J. Girnius, przedm. Vilnius, Vyturys (reprint wydania: Los Angeles 1951).

Gorbaniewska N., 2012: Nie traktat, a traktat wierszem. „Poznańskie Studia Polonistyczne", nr 20, s. 211-214.

Greimas A.J., 1959: Sąmonè ir sąžine (Cz. Miloszo poezijos verrtimus perskaičius). „Literatūros lankai”, nr 8, s. 9.

Kalęba B., 2014a: Czesław Miłosz i litewscy „Kolumbowie”. Przyczynek do jeszcze jednej biografii równoległej. „Wielogłos”, nr 2 (20), s. 65-80.

Kalęba B., 2014b: Nota. „Kwartalnik Artystyczny”, nr 2 (82), s. 25-26.

Kalęba B., oprac., 2020: Bibliografia przedmiotowa Czesława Miłosza w języku litewskim. W: A. Fiut, E. Pasierski, oprac. S. Bill et al., współpr.: Czesław Miłosz. Bibliografia przedmiotowa 1932-2020. Wybór. Kraków, Wydawnictwo Literackie.

Kasner M., 1999: Czesław Miłosz i „Literatūros lankai” (1952-1959). „Tygiel Kultury", nr 10-12, s. 146-154.

Kita-Huber J., Makarska R., 2020: Wyjść tłumaczowi naprzeciw. Wprowadzenie. W: Eaedam, red.: Wyjść tłumaczowi naprzeciw. Miejsce tłumacza w najnowszych badaniach translatologicznych. Kraków, TAiWPN Universitas.

Milosz Czeslaw [hasło]. Dostępne w Internecie: http://aidai.eu/index.php?option =com_content\&view=article\&id=1576:m\&catid=142:asmenvardi-rodykl\&Itemid=166 [dostęp: 16.02.2021].

Milosz C., 1955: Nevilties apgultieji. Fragmentai iš romano „Valdžios paèmimas“. J. Kèkštas, tłum. „Literatūros lankai”, nr 6, s. 10-12.

Milosz C., 1959: Mickevičius ir istorijos paradoksai. J. Kèkštas, tłum. „Literatūros lankai", nr 8, s. 2.

Miłosz C., 1952: Ǐžanga; Himnas. J. Kèkštas, tłum. „Literatūros lankai”, nr 1, s. 12.

Miłosz C., 1955: Epochos sq̨moningumo poezija. Su autoriaus įvadiniu žodžiu, vertè ir redagavo J. Kèkštas, užsklandą parašè A. Nyka-Niliūnas. Buenos Aires, Literatūros lankai.

Miłosz C., 2001: Traktat poetycki z moim komentarzem. Kraków, Wydawnictwo Literackie.

Miłosz C., 2014: Przedmowa [do litewskiego wyboru wierszy Miłosza Epochos sąmoningumo poezija (Buenos Aires 1955)]. „Kwartalnik Artystyczny”, nr 2 (82), s. 13-24.

Miłosz C., 2018: Idee O. Miłosza oraz Rozmyślania o czasie pożogi. B. Kalęba, tłum. W: Idem: W cieniu totalitaryzmów. Publicystyka rozproszona 
$z$ lat 1945-1952 oraz teksty $z$ okresu II wojny światowej. A. Fiut et al., red. Kraków, Wydawnictwo Literackie.

Miłosz C., 2021: Traktat poetycki $z$ moim komentarzem. Poetinis traktatas su mano komentarais. T. Venclova, ị lietuvių kalbą vertè. Vilnius, Apostrofa.

Nyka-Niliūnas A., 1955: [Posłowie]. W: C. Miłosz: Epochos sąmoningumo poezija. Su autoriaus įvadiniu žodžiu, verte ir redagavo J. Kèkštas, užsklandą parašè A. Nyka-Niliūnas. Buenos Aires, Literatūros lankai.

Poderienė I., Montvilienė E., Raišytė R., 2006: „Akiračių” bibliografija. Vilnius, Versus aureus.

Venclova T., 1983: Lata wytrwałości. A.A., tłum. „Zeszyty Literackie”, nr 4 (8), s. $41-48$.

Venclova T., 1990: Tankejjanti šviesa. Chicago, AMKLF.

Venclova T., 2011: Rozpacz i łaska oraz Poezja jako pokuta. W: C. Miłosz, T. Venclova: Powroty do Litwy. B. Toruńczyk, wyb., oprac. M. Nowak-Rogoziński, współpr. Warszawa, Fundacja Zeszytów Literackich.

Venclova T., 2012: Bibliografijos rodykle. Bibliographic index. Bibliografia 19562011. Vilnius, LNMB.

Venclova T., 2013: Lietuviu poezija. W: Idem: Pertrūkis tikroveje. Straipsniai apie literatūrą ir kultūrą. Vilnius, LLTI.

Venclova T., 2016: Magnetyczna Północ. E. Hinsey, rozm. M. Ochab, tłum. Warszawa, Fundacja Zeszytów Literackich.

Venclova T., 2020: Dajesz, Baltušis! Patriota na sterydach. B. Kalęba, tłum. „Gazeta Wyborcza”, 24.12.2020. Dostępne w Internecie: https://wyborcza.pl/ magazyn/7,124059,26632612, dajesz-baltusis-patriota-na-sterydach.html [dostęp: 5.08.2021].

Venclova T., 2021: Słowo tłumacza do litewskiego czytelnika. B. Piasecka, tłum. W: C. Miłosz: Traktat poetycki z moim komentarzem. Poetinis traktatas su mano komentarais. T. Venclova, ị lietuvių kalbą verte. Vilnius, Apostrofa.

\section{Beata Kalęba \\ Długa droga do litewskiego przekładu \\ Traktatu poetyckiego Czesława Miłosza}

STRESZCZENIE | W 2021 roku ukazał się litewski przekład Traktatu poetyckiego Czesława Miłosza pióra Tomasa Venclovy. Niniejszy artykuł powstał z inspiracji tym wydarzeniem literackim. Pierwsza część szkicu jest poświęcona rekonstrukcji obecności utworów Miłosza w litewskiej literaturze przekładowej od lat 30. XX wieku po dziś dzień oraz miejscu Miłosza w edukacji literackiej w litewskich i polskich szkołach na Litwie. O ile w szkołach Miłosz jest czytany przede wszystkim przez pryzmat obecnych w jego utworach tematów i motywów litewskich, o tyle historia tłumaczeń ukazuje, że zainte- 
resowanie nim wśród Litwinów rozwijało się dwutorowo: po pierwsze - ze względu na osobiste kontakty pisarza nawiązane jeszcze przed II wojną światową w Wilnie (np. z poetą i tłumaczem Juozasem Kèkštasem); po wtóre - ze względu na to, że problematyka twórczości Miłosza, zwłaszcza tej z lat 40., 60., odpowiadała na potrzeby intelektualne i estetyczne części pisarzy i intelektualistów litewskich tamtego czasu. Chodzi tu o środowisko emigracyjne, reprezentowane przez literatów i artystów skupionych wokół czasopisma „Literatūros lankai” (1952-1959) oraz intelektualistów związanych z liberalnym ruchem Santara-Šviesa (1957); to jemu poświęcona jest druga część artykułu.

SŁOWA KLUCZOWE | przekład, Czesław Miłosz, Tomasz Venclova, Traktat poetycki, język litewski

\section{Beata Kalęba}

\section{A Long Way to the Lithuanian Translation of Czesław Miłosz's A Treatise on Poetry}

SUMMARY | In 2021 Tomas Venclova's Lithuanian traduction of Czeslaw Milosz's Treatise on Poetry was published. The present article originated as a result of the author's inspiration provoked by this event. Its first part's aim is to reconstruct Miłosz's work's footprint in Lithuanian traductory literature from 1930s' until present and item his footprint in education at both Lithuanian and Polish schools in Lithuania. Whereas in class Milosz is primarily read through the prism of Lithuanian affaires and motives existing in his works, history of traduction indicates that Lithuanians' interest about him has developed in a twin-track approach: firstly - due to the privaet acquaitances made before World War II in Vilnius (ex. with a poet and a translator Juozas Kekstas), and secondly due to the fact that the issues brought up by Czeslaw Milosz (especially those from 1940s' to 1960s') corresponded with the intellectual and esthetical needs of some Lithuanian thinkers those days. And that's about the emigrant environment represented by literates and artists gathered around the magazine "Literatūros lankai" (1952-59) and intellectualists associated with the liberal movement of Santara-Šviesa (1957) — those, to which the second part of the article is devoted.

KEYWORDS | translation, Czesław Miłosz, Tomas Venclova, A Treatise on Poetry, Lithuanian language

BEATA KALĘBA | dr hab. nauk humanistycznych, adiunkt na Wydziale Polonistyki Uniwersytetu Jagiellońskiego; historyczka literatury polskiej i litewskiej, tłumaczka z języka litewskiego. Prowadzi badania komparatystyczne nad pograniczem polsko-litewskim w XIX i XX wieku, związkami twórczości Czesława Miłosza i litewskich pisarzy na wychodźstwie oraz nad twórczością Tomasa Venclovy. Jej zainteresowania naukowe koncentrują się także na teorii i praktyce przekładu. Autorka monografii Rozdroże. Literatura polska w kręgu litewskiego odrodzenia narodowego (2016) i Wyrwa w świecie. Przekład literacki w radzieckiej Litwie - casus Tomasa Venclovy i rówieśników (2019) oraz skryptu 
do historii literatury litewskiej Widziałem świat (2014). Współautorka trzytomowego wyboru publicystyki $W$ kręgu sporów polsko-litewskich na przełomie XIX i XX wieku (2004, 2009, 2011). Tłumaczka literatury naukowej (m.in. Mindaugasa Kvietkauskasa Polifonia literatury $w$ Wilnie okresu wczesnego modernizmu 1904-1915) oraz literatury pięknej (głównie utworów Tomasa Venclovy i litewskich pisarzy emigracyjnych). 